\title{
KARAKTERISTIK CURAH HUJAN BERDASARKAN RAGAM TOPOGRAFI DI SUMATERA UTARA
}

\author{
Variable Topography-Based Rainfall Characteristic in North Sumatera
}

\author{
Budi Prasetyo ${ }^{1)^{*}}$, Hendri (rwandi2), Nikita Pusparini ${ }^{2)}$ \\ 1) Balai Besar Meteorologi Klimatologi dan Geofisika Wil I - Medan, \\ Jalan Ngumban Surbakti No. 15 Selayang II Medan \\ 2) Stasiun Klimatologi Deli Serdang, Badan Meteorologi Klimatologi dan Geofisika (BMKG), \\ Jalan Meteorologi Raya No.17 Sampali Medan \\ `E-mail : bo3di.kecil@gmail.com
}

\begin{abstract}
Intisari
Wilayah Sumatera Utara (Sumut) memiliki kondisi geografis dan topografi yang beragam, mulai dari pesisir, dataran rendah, dataran tinggi, pegunungan, serta kepulauan. Hal ini dapat menyebabkan variabilitas curah hujan semakin beragam. Untuk itu, kajian ini akan membahas mengenai variabilitas curah hujan Sumut di beberapa wilayah dengan kondisi geografi dan topografi yang berbeda. Data curah hujan bulanan dari 17 pos hujan Badan Meteorologi Klimatologi dan Geofisika (BMKG) dengan periode 1986-2016 (31 tahun) digunakan dalam kajian ini. Metode analisis deskriptif, statistik sederhana berupa perata-rataan, standarisasi anomali, dan interpolasi pembalikkan bobot jarak digunakan dalam kajian ini. Letak pos hujan dibagi berdasarkan kondisi geografis dan topografinya sehingga diperoleh enam wilayah yaitu Pesisir Timur, Lereng Timur, Pegunungan, Lereng Barat, Pesisir Barat, dan Kepulauan Nias. Hasil yang diperoleh yaitu variabilitas curah hujan Sumut dalam skala bulanan, antar musiman dan antar tahunan di keenam wilayah topografi berbeda satu sama lain. Curah hujan rata-rata Sumut umumnya menurun dari wilayah Barat ke Timur sehingga menyebabkan perbedaan yang cukup signifikan antara wilayah Timur dan Barat. Curah hujan tertinggi terjadi di wilayah Pesisir Barat yaitu $230-570 \mathrm{~mm} /$ bulan atau $>4550 \mathrm{~mm} / \mathrm{tahun}$ sedangkan terendah terjadi di Pesisir Timur yaitu 100-150 mm/bulan atau 1500-2000 mm/tahun. Puncak musim hujan Sumut umumnya terjadi pada bulan November, kecuali wilayah Pesisir dan Lereng Timur yang terjadi pada bulan Oktober. Curah hujan tahunan wlayah topografi Sumut umumnya menunjukkan nilai anomali standar negatif pada tahun 90-an dan menunjukkan anomali positif setelah tahun 2000, kecuali di wilayah Lereng Timur dan Kepulauan.
\end{abstract}

Kata Kunci : Curah Hujan, Topografi, Sumatera Utara.

\begin{abstract}
The region of North Sumatra (Sumut) has a varied geographical and topographical conditions, with features ranging from coastal, lowland, highlands, mountains, and islands. These can lead to a varying degree of rainfall variability. This study discussed North Sumatra rainfall variability with some areas having different geographical and topographical conditions. Monthly rainfall data from 17 observation stations of the Agency for Meteorology, Climatology, and Geophysics (BMKG) for the period of 1986-2016 (31 years) were used in this study. Descriptive analysis methods, simple statistics, anomaly standardization, and Inverse Distance Weights (IDW) interpolation were also used as an analytical tool? in this study. The location of observation stations are categorized based on geographical and topographical condition. These are East Coast, East Slope, Mountains, West Slope, West Coast, and Nias Islands. The results showed that the monthly, inter-seasonal and interannual scale of North Sumatra rainfall variability on all the six topographic areas were different compared to each other. The average rainfall of North Sumatra generally decreased from the West to East, causing significant differences between regions located in the East and in the West. The highest rainfall that occurred in the West Coast region is $230-570 \mathrm{~mm} / \mathrm{month}$ or $>4550 \mathrm{~mm} / \mathrm{year}$, whereas the lowest rainfall that occurred in the East Coast region is $100-150 \mathrm{~mm} / \mathrm{month}$ or 1500 $2000 \mathrm{~mm} /$ year. The peak of North Sumatera rainfall season generally occurs during the month of November, except in the Eastern coast and slope area which occurs during October. Annual rainfall generally showed negative anomaly standard value during the 90s and positive anomaly after the year 2000 except in the Eastern Slope and Islands region.
\end{abstract}

Keywords : Rainfall, Topography, North Sumatra. 


\section{PENDAHULUAN}

Benua Maritim Indonesia (BMI) memiliki variabilitas curah hujan yang tinggi. Curah hujan BMI dipengaruhi oleh beragam faktor cuaca/iklim, baik global maupun lokal sehingga dapat bersifat harian (Mori et al., 2004; Yulihastin et al., 2010), antar musiman (Tjasyono \& Banu, 2003) dan antar tahunan (Hidayat et al., 2016). Beberapa kawasan di wilayah BMI memiliki curah hujan yang sangat beragam termasuk wilayah Sumatera Utara (Sumut).

Provinsi Sumut merupakan salah satu provinsi yang terletak di Pulau Sumatera Bagian Utara dengan koordinat $1^{\circ}-4^{\circ} \mathrm{LU}$ dan $98^{\circ}-100^{\circ}$ BT. Kondisi geografis Sumut cukup strategis karena terletak di sekitar garis ekuatorial, dilalui oleh pegunungan Bukit Barisan dan diapit oleh Selat Malaka dan Samudera Hindia. Hal ini menyebabkan kondisi iklim curah hujan Sumut memiliki karakteristik iklim yang dipengaruhi oleh iklim global seperti fenomena Indian Ocean Dipole (IOD) (Gustari, 2009), Inter Tropical Convergenze Zone (ITCZ), Madden Julian Oscillation (MJO), maupun El Niño Southern Oscillation (ENSO). Selain itu, faktor iklim skala regional seperti monsun, gangguan tropis, serta daerah konvergensi juga mempengaruhi kondisi iklim di daerah tersebut. Pada skala lokal, pertumbuhan awan dan hujan mendapat pengaruh dari kondisi alam tersebut dan juga mendapat pengaruh dari pergerakan semu matahari.

Faktor topografi dan sistem cuaca regional memiliki peran penting dalam jumlah dan pola spasial curah hujan dalam suatu wilayah (Enyew \& Steenveld, 2014). Proses awal untuk memahami pengaruh dari pola-pola cuaca dan iklim secara kualitatif dan kuantitatif dilakukan dengan mengkaji interaksi daratan, lautan dan topografi wilayah dalam skala lokal (Hermawan, 2010). Pola spasial curah hujan memiliki korelasi yang kuat dengan topografi suatu wilayah (Anders et al, 2006). Selain itu, kondisi fisik geografis dapat digunakan untuk indikasi distribusi spasial dari curah hujan (Subyani et al., 2010; Duran, 2014). Adanya topografi yang tidak rata, misalnya akibat pegunungan, juga terlihat berpengaruh terhadap curah hujan yang terjadi. Hal ini sesuai dengan penelitian Flesch \& Reuter (2012) yang melakukan penelitian menggunakan model Weather Research and Forecasting (WRF) di Provinsi Alberta, Kanada, menyatakan bahwa adanya pegunungan Rocky berpengaruh terhadap tingginya curah hujan maksimum. Dengan penurunan ketinggian gunung, hasil WRF memberikan pengurangan tingkat curah hujan maksimum di atas gunung dan kaki bukit sebesar $50 \%$, dengan pengendapan di cekungan yang terkena banjir berkurang sebesar $15-45 \%$. Lebih lanjut lagi, terdapat pengaruh efek lokal topografi yang membuat variabilitas curah hujan semakin besar (Roe, 2005; Zhou et al., 2013).

Mengingat kondisi topografi Sumatera Utara yang cukup kompleks karena terdiri dari pegunungan, pesisir, dataran tinggi, dan dataran rendah, maka analisis karakteristik curah hujan terhadap topografi menjadi topik yang menarik untuk dibahas.

Variabitas curah hujan juga berdampak pada bidang pertanian yang secara tidak langsung juga berpengaruh kepada keamanan bahan pangan, kesejahteraan kehidupan dan ekonomi sosial di masyarakat (Baidu et al., 2017). Informasi mengenai pola cuaca dan iklim curah hujan akan sangat membantu dalam proses perencanaan dan kegiatan cocok tanam yang dilakukan di wilayah Sumut dengan kondisi topografi yang beragam. Perbedaan kondisi lokasi dan topografi akan menyebabkan kondisi cuaca maupun iklim menjadi berbeda. Dengan demikian, kajian ini akan membahas mengenai variabilitas karakteristik curah hujan di wilayah Sumut terkait dengan perbedaan topografi wilayahnya. Hasil penelitian ini diharapkan mampu menjelaskan mengenai karakteristik curah hujan di wilayah Sumut pada topografi yang berbeda.

\section{METODE}

Kajian ini difokuskan di wilayah Sumatera Utara dengan koordinat $1^{\circ}-4^{\circ} \mathrm{LU}$ dan $98^{\circ}-100^{\circ}$ BT (Gambar 1).

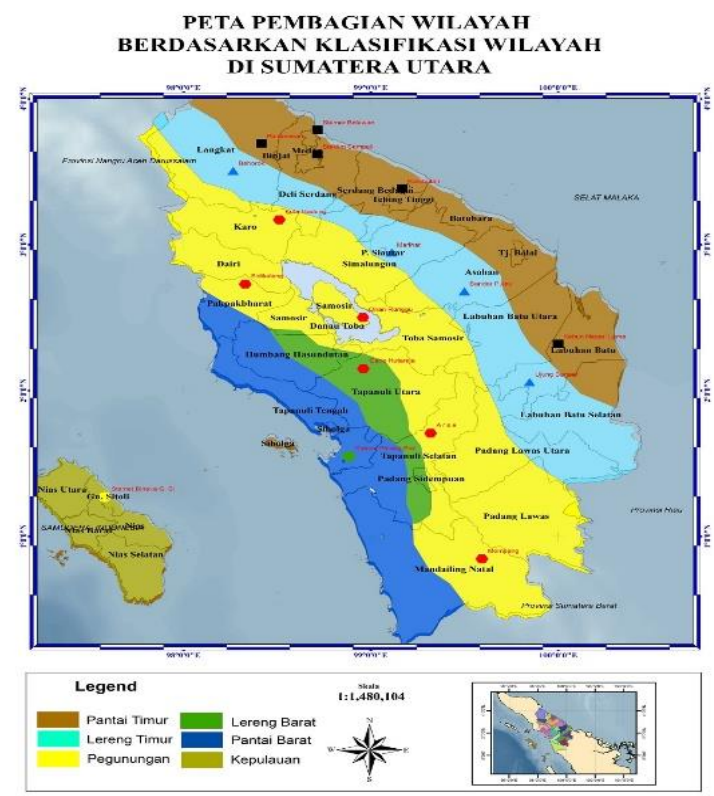

Gambar 1. Provinsi Sumatera Utara dan lokasi penakar curah hujan.

Data yang digunakan yaitu data curah hujan dasarian (sepuluh harian) hasil pengukuran penakar hujan yang diperoleh dari Badan Meteorologi Klimatologi dan Geofisika (BMKG) selama 31 tahun yaitu mulai dari Januari 1986 
Tabel 1. Informasi Lokasi Pos Hujan di Wilayah Sumatera Utara.

\begin{tabular}{clccc}
\hline No & \multicolumn{1}{c}{ Stasiun } & Lintang & Bujur & Periode \\
\hline $\mathbf{1}$ & Pardamean & $3.75^{\circ} \mathrm{N}$ & $98.44^{\circ} \mathrm{E}$ & Jan1986 - Des2016 \\
\hline $\mathbf{2}$ & Sampali & $3.62^{\circ} \mathrm{N}$ & $98.78^{\circ} \mathrm{E}$ & Jan1986 - Des2016 \\
\hline $\mathbf{3}$ & Stamar Belawan & $3.78^{\circ} \mathrm{N}$ & $98.71^{\circ} \mathrm{E}$ & Jan1986 - Des2016 \\
\hline $\mathbf{4}$ & Rambutan & $3.38^{\circ} \mathrm{N}$ & $99.16^{\circ} \mathrm{E}$ & Jan1986 - Des2016 \\
\hline $\mathbf{5}$ & Negeri Lama & $2.32^{\circ} \mathrm{N}$ & $100.0^{\circ} \mathrm{E}$ & Jan1986 - Des2016 \\
\hline $\mathbf{6}$ & Bahorok & $3.50^{\circ} \mathrm{N}$ & $98.13^{\circ} \mathrm{E}$ & Jan1986 - Des2016 \\
\hline $\mathbf{7}$ & Marihat & $2.91^{\circ} \mathrm{N}$ & $99.08^{\circ} \mathrm{E}$ & Jan1986 - Des2016 \\
\hline $\mathbf{8}$ & Bandar Pulau & $2.65^{\circ} \mathrm{N}$ & $99.50^{\circ} \mathrm{E}$ & Jan1986 - Des2016 \\
\hline $\mathbf{9}$ & Ujung Bandar & $2.06^{\circ} \mathrm{N}$ & $99.85^{\circ} \mathrm{E}$ & Jan1986 - Des2016 \\
\hline $\mathbf{1 0}$ & Sidikalang & $2.73^{\circ} \mathrm{N}$ & $98.33^{\circ} \mathrm{E}$ & Jan1986 - Des2016 \\
\hline $\mathbf{1 1}$ & Kuta Gadung & $3.15^{\circ} \mathrm{N}$ & $98.50^{\circ} \mathrm{E}$ & Jan1986 - Des2016 \\
\hline $\mathbf{1 2}$ & Onan Runggu & $2.50^{\circ} \mathrm{N}$ & $98.95^{\circ} \mathrm{E}$ & Jan1986 - Des2016 \\
\hline $\mathbf{1 3}$ & Gabehutaraja & $2.11^{\circ} \mathrm{N}$ & $98.95^{\circ} \mathrm{E}$ & Jan1986 - Des2016 \\
\hline $\mathbf{1 4}$ & Arse & $1.70^{\circ} \mathrm{N}$ & $99.32^{\circ} \mathrm{E}$ & Jan1986 - Des2016 \\
\hline $\mathbf{1 5}$ & Mompang & $0.91^{\circ} \mathrm{N}$ & $99.53^{\circ} \mathrm{E}$ & Jan1986 - Des2016 \\
\hline $\mathbf{1 6}$ & Pinangsori & $1.55^{\circ} \mathrm{N}$ & $98.88^{\circ} \mathrm{E}$ & Jan1986 - Des2016 \\
\hline $\mathbf{1 7}$ & G.Sitoli & $1.27^{\circ} \mathrm{N}$ & $97.58^{\circ} \mathrm{E}$ & Jan1986 - Des2016 \\
\hline
\end{tabular}

hingga Desember 2016. Curah hujan dasarian kemudian diubah ke dalam bentuk bulanan. Data tersebut berasal dari 17 pos hujan yang tersebar di wilayah Sumut (Tabel 1) dengan lokasi/topografi yang beragam yaitu Pesisir Timur, Lereng Timur, Pegunungan, Lereng Barat, Pesisir Barat hingga kepulauan (Gambar 1). Data curah hujan hasil penakaran memberikan gambaran yang lebih baik di suatu wilayah dibandingkan produk hasil dari penggabungan satelitpengamatan, data satelit turunan, dan hasil model reanalisis (Manzanas et al., 2014). Penelitian ini menggunakan metode analisis deskriptif yaitu hasil dari suatu kegiatan yang mendeskripsikan sesuatu dengan mengacu kepada referensi dan data dari lapangan (Pabalik et al., 2015). Analisis variabilitas curah hujan bulanan, musiman dan tahunan dilakukan menggunakan perhitungan statistik berupa perata-rataan dan penjumlahan curah hujan. Analisis variabilitas musiman dibagi menjadi empat yaitu periode Januari-FebruariMaret (JFM), April-Mei-Juni (AMJ), Juli-AgustusSeptember (JAS) dan Oktober-NopemberDesember (ONS). Pembagian periode ini mengikuti pola hujan wilayah Sumut yang sebagian besar bersifat bimodal (Aldrian \& Susanto, 2003).

Analisis variabilitas tahunan merupakan hasil dari penjumlahan data curah hujan bulanan dalam setahun. Perhitungan anomali standarisasi digunakan berdasarkan metode yang digunakan oleh Wilks et al. (2006), Manzanas et al. (2014), dan Baidu et al. (2017) dengan tujuan menghilangkan pengaruh dari lokasi dan sebaran sejumlah data. Anomali standarisasi dihitung dengan mengurangi rata-rata sampel dari data time series dan membaginya dengan standar deviasinya, berikut formulanya (Wilks, 2006):

$$
Z=\frac{x-\bar{x}}{s_{x}}
$$

dengan $\mathrm{x}=$ data time series curah hujan, $\bar{x}=$ ratarata curah hujan dan, $\mathrm{Sx}=$ standar deviasi. Ratarata berjalan 5 tahunan diaplikasikan pada hasil dari anomali standarisai curah hujan tahunan.

Anomali curah hujan digunakan untuk menganalisis kelebihan ataupun kekurangan curah hujan yang terjadi dalam suatu waktu. Perhitungan anomali curah hujan dilakukan dengan mengurangkan suatu data deret waktu terhadap data normalnya di suatu wilayah. Anomali positif menunjukkan bahwa curah hujan pada waktu tersebut lebih tinggi dibandingkan normalnya. Begitu sebaliknya, anomali negatif menunjukkan curah hujan lebih rendah dibandingkan kondisi normalnya.

Analisis curah hujan di wilayah Sumut dikelompokkan berdasarkan wilayah topografinya. Pembagian pengelompokkan wilayah berdasarkan topografi wilayah Sumut dan lokasi pos hujan. Wilayah dengan topografi yang relatif sama menjadi suatu wilayah tertentu dan luasan wilayahnya diinterpretasi dengan metode analisis spasial. Menurut Badan Pusat Statistik (BPS) (2017), Sumatera Utara dibagi menjadi 3 (tiga) wilayah utama antara lain: Wilayah Pantai Timur, Pegunungan dan Pantai Barat.

Dalam penelitian ini wilayah utama akan dibagi menjadi wilayah yang lebih detail dengan kriteria sebagai berikut: 
a. Wilayah Pantai, merupakan wilayah dataran rendah/pantai dengan ketinggian berkisar antara (0-200 m) yang berbatasan dengan Selat Malaka di Pantai Timur dan Samudera Hindia di Pantai Barat.

b. Wilayah Lereng, merupakan wilayah dataran tinggi yang memiliki topografi landai berbukit dan sebagian terjal dengan ketinggian berkisar antara 201 - $1200 \mathrm{~m}$. Kawasan topografi juga dibagi menjadi 2 wilayah yaitu Lereng Barat dan Lereng Timur.

c. Wilayah Pegunungan, merupakan wilayah dengan topografi >1200 m yang umumnya berada di sekitar pegunungan.

d. Wilayah Kepulauan khusus diberikan untuk wilayah Pulau Nias. Hal ini disebabkan wilayah tersebut yang dikelilingi oleh Laut dan terpisah dari wilayah Sumut yang berada di Pulau Sumatera.

Berdasarkan hal tersebut, maka wilayah Sumut terbagi menjadi 6 wilayah sesuai topografi Sumut dan pos hujan yang mewakilinya (Tabel 2).

Tabel 2. Pembagian Wilayah Topografi.

\begin{tabular}{ll}
\hline \multicolumn{1}{c}{ Wilayah } & \multicolumn{1}{c}{ Pos Hujan } \\
\hline Pesisir Timur & $\begin{array}{l}\text { Pardamean, Sampali, } \\
\text { Rambutan, dan Belawan }\end{array}$ \\
\hline Pesisir Barat & PinangSori \\
\hline Lereng Timur & $\begin{array}{l}\text { Ujung Bandar, Marihat, Negeri } \\
\text { Lama, dan Bandar Pulau }\end{array}$ \\
\hline Pegunungan & $\begin{array}{l}\text { KutaGadung, Sidikalang, } \\
\text { Onanrunggu, Arse, Mompang } \\
\text { dan Bahorok }\end{array}$ \\
\hline Lereng Barat & Gabe Hutaraja \\
\hline Kepulauan & Binaka \\
\hline
\end{tabular}

Peta spasial curah hujan dibuat dengan menggunakan teknik interpolasi pembalikan bobot jarak atau yang lebih dikenal dengan interpolasi Inverse Distance Weight (IDW). Metode interpolasi IDW memiliki kualitas baik dan mudah diimplementasikan pada Sistem Informasi Geografis (SIG) (Yang et al, 2015). Proses Interpolasi IDW secara eksplisit menerapkan asumsi bahwa hal-hal yang berdekatan lebih mirip daripada yang terpisah jauh. IDW akan menggunakan nilai terukur yang yang berada di sekitar lokasi prediksi untuk memprediksi nilai pada lokasi yang tidak terukur. Nilai terukur yang terdekat dengan lokasi prediksi akan memiliki pengaruh lebih besar terhadap nilai prediksi daripada yang lebih jauh. Dengan demikian, IDW mengasumsikan bahwa setiap titik yang diukur memiliki pengaruh lokal yang berkurang dengan jarak.

\section{HASIL DAN PEMBAHASAN}

\subsection{Variabilitas Curah Hujan Bulanan}

Hasil perhitungan rata-rata selama 31 tahun menunjukkan bahwa curah hujan Sumut berkisar antara 130 hingga $290 \mathrm{~mm} /$ bulan.
Puncak curah hujan tertinggi terjadi pada bulan November $(294 \mathrm{~mm})$ dan puncak kedua terjadi pada bulan April (205 mm), sedangkan yang terendah terjadi pada Februari $(137 \mathrm{~mm})$ dan Juni (139 mm) (Gambar 2.a).

Curah hujan bulanan Sumut umumnya berpola ekuatorial yang bersifat bimodal yang terdiri dari dua puncak dan dua lembah, sesuai dengan hasil penelitian Tjasyono et al. (1999) serta Adrian \& Susanto (2003). Curah hujan Sumut pada bulan Februari merupakan yang terendah dibandingkan bulan lainnya. Peningkatan curah hujan terjadi saat bulan Maret dan mencapai puncaknya pada bulan April, kemudian mengalami penurunan kembali hingga mencapai bulan Juni. Kenaikan kembali terjadi setelah itu dan terus meningkat hingga mencapai puncak musim hujan tertinggi di Sumut yang terjadi pada bulan November. Curah hujan kembali turun cukup signifikan pada bulan Januari dan terus menurun hingga bulan Februari.

Puncak curah hujan Sumut terjadi pada bulan April dan November, satu bulan lebih lambat seperti yang dikemukakan oleh Aldrian \& Susanto (2003). Hal ini dapat disebabkan oleh letak wilayah Sumut yang berada pada lintang $1-4^{\circ} \mathrm{LU}$ sehingga posisi matahari yang berada di atas wilayah Sumut lebih lambat 1 bulan dari ekuinoks matahari pada bulan Maret dan Oktober. Aktivitas matahari berpengaruh terhadap kondisi curah hujan suatu wilayah bergantung pada waktu dan posisi geografiknya. Posisi Matahari yang berada di sekitar ekuator menyebabkan suhu permukaan laut menghangat, sehingga wilayah sekitar ekuator mendapat asupan massa udara basah (Sinambela et al., 2008). Hal ini dapat menyebabkan pertambahan pertumbuhan awan dan hujan.

Secara spasial, rata-rata curah hujan dengan intensitas tinggi umumnya terjadi di wilayah Pesisir Barat yaitu di Sibolga dan sekitarnya dengan intensitas berkisar antara 300$400 \mathrm{~mm}$, sedangkan yang terendah terjadi di wilayah Pesisir Timur yaitu 100-150 mm. Wilayah dataran tinggi seperti Lereng Barat dan Lereng Timur memiliki curah hujan rata-rata $200-250 \mathrm{~mm}$, sementara wilayah Pegunungan memiliki curah hujan rata-rata yang lebih rendah yaitu 150-200 $\mathrm{mm}$ (Gambar 2.b). Peningkatan curah hujan umumnya dimulai dari Pesisir Timur hingga ke Pesisir Barat dengan penurunan terjadi di wilayah Pegunungan.

Intensitas curah hujan berdasarkan wilayah topografi Sumut sangat beragam mulai dari 90 $560 \mathrm{~mm} /$ bulan. Curah hujan rata-rata bulanan Pesisir Barat Sumut merupakan yang tertinggi sepanjang tahun dibandingkan wilayah Sumut lainnya, dengan nilai berkisar antara $290-560 \mathrm{~mm}$. Curah hujan bulanan terendah saat musim kemarau (Januari-Juni) terjadi di wilayah Pesisir Timur, sedangkan saat musim hujan (JuliDesember) terjadi di wilayah Lereng Barat. 

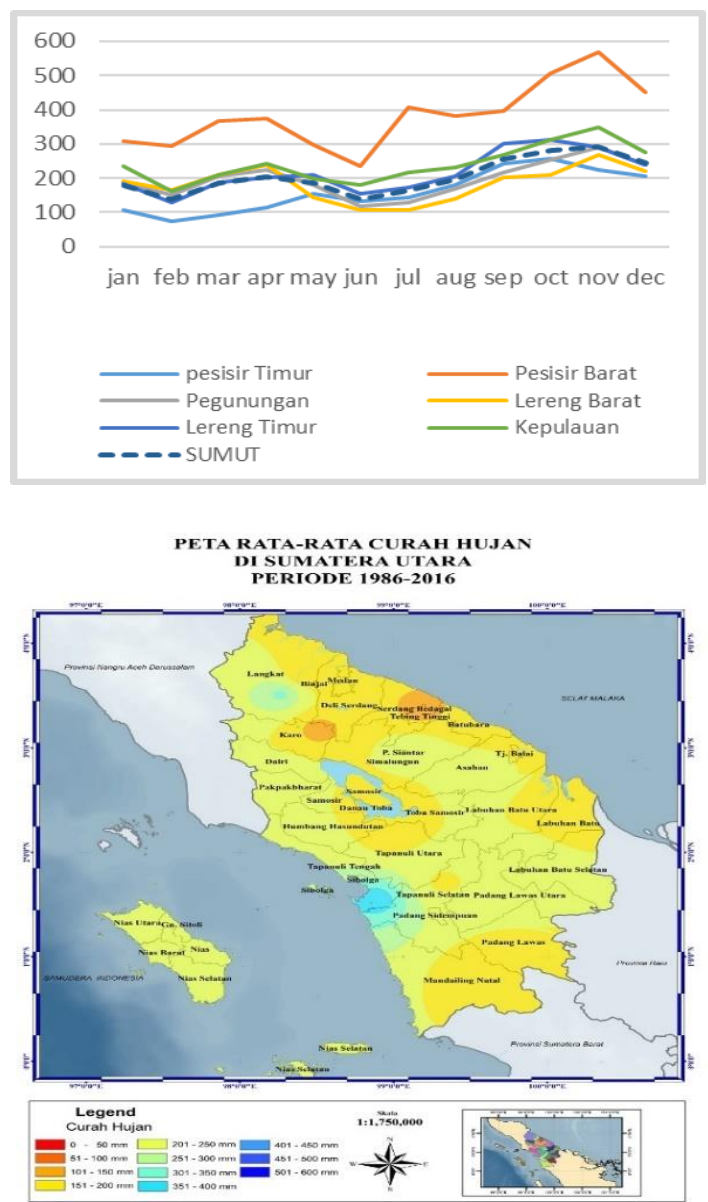

Gambar 2. (a). Grafik rata-rata curah hujan bulanan Sumut berdasarkan wilayah topografi; (b). Peta spasial curah hujan rata-rata Sumut.

Pola curah hujan pada keenam wilayah topografi Sumut umumnya memiliki pola yang sama yaitu bersifat bimodal. Hal yang berbeda terjadi pada puncak musim hujan tertinggi di wilayah Pesisir Timur dan Lereng Timur yang terjadi lebih cepat dibandingkan kondisi normal puncak musim hujan Sumut, yaitu terjadi pada bulan Oktober. Perbedaan terjadi saat puncak musim kemarau antara wilayah bagian Barat dan Timur yaitu curah hujan terendah terjadi di wilayah Sumut Bagian Barat (Pesisir Barat, Lereng Barat dan Pegunungan, kecuali Kepulauan Nias) yang terjadi pada bulan Juni, sedangkan wilayah Sumut Bagian Timur (Pesisir Timur, dan Lereng Timur) terjadi pada bulan Februari. Kepulauan Nias merupakan wilayah Barat Sumut, namun curah hujan terendahnya terjadi sesuai dengan wilayah Timur Sumut. Hal ini dapat disebabkan curah hujan di kepulauan Nias dipengaruhi oleh sistem cuaca yang berasal dari wilayah lautan yaitu Samudera Hindia. Hal yang sama terjadi di wilayah Pesisir Timur dan Lereng Timur yang dipengaruhi oleh Selat Malaka.

\subsection{Curah Hujan Musiman}

Curah hujan musiman Sumut umumnya meningkat dari periode JFM ke periode AMJ kemudian turun kembali pada periode JAS, dan puncak curah hujan musiman umumnya terjadi pada periode OND. Perbedaan signifikan curah hujan musiman Sumut juga terjadi antara pesisir Barat (tertinggi) dan pesisir Timur (terendah). Wilayah Kepulauan Nias dan dataran tinggi (Lereng dan Pegunungan) terlihat memiliki curah hujan yang relatif mirip.

Curah hujan pada periode JFM berkisar antara 80-350 mm (Gambar 3.a). Curah hujan Pesisir Timur merupakan yang terendah dibandingkan wilayah lainnya. Peta hasil interpolasi menunjukkan perbedaan wilayah pesisir Timur terhadap wilayah lainnya terlihat cukup mencolok. Wilayah dataran tinggi (Lereng dan Pegunungan), Pesisir Barat dan Kepuluaun memiliki curah hujan relatif sama. Wilayah Pesisir Barat merupakan wilayah dengan curah hujan tertinggi, namun sebagian wilayah pesisir Barat seperti di Kabupaten Tapanuli Tengah dan Kota Padang Sidimpuan memiliki curah hujan yang relatif sama dengan wilayah Kepulauan.

Curah hujan periode AMJ umumnya lebih tinggi dibandingkan periode JFM. Perbedaan curah hujan antar wilayah Sumut tidak terlalu mencolok dibandingkan pada periode JFM. Curah hujan terendah terjadi di sebagian Pesisir Timur (Serdang Bedagai hingga Medan), Karo dan Mandailing Natal (Gambar 3.b). Fluktuasi yang terjadi dari periode AMJ ke JAS tidak terlalu signifikan. Curah hujan Sumut pada periode JAS umumnya mengalami penurunan dibandingkan periode AMJ, namun pada beberapa wilayah mengalami peningkatan yang cukup signifikan seperti di sebagian Kabupaten Asahan, Tanjung Balai, Langkat, Sibolga dan Labuhan Batu (Gambar 3.c).

Curah hujan Sumut periode OND merupakan curah hujan tertinggi dibandingkan periode lainnya. Intensitas curah hujan berkisar antara $160-450 \mathrm{~mm}$ dengan yang tertinggi tetap terjadi di Wilayah Sibolga dan terendah terjadi di sepanjang Pantai Timur Sumut mulai dari Kabupaten Serdang Bedagai hingga sebagian Kabupaten Karo (Gambar 3.d).

Variasi curah hujan musiman Sumut berdasarkan topografi cukup beragam mulai dari pola hingga intensitasnya. Wilayah topografi Pegunungan, Lereng Barat dan Timur, serta Kepulauan mengikuti pola yang sama seperti Sumut. Keempat wilayah tersebut memiliki curah hujan yang hampir sama pada periode JFM dan AMJ. Perubahan terjadi pada periode JAS dimana curah hujan wilayah Pegunungan dan Lereng Barat menurun cukup drastis sehingga berada pada tempat yang paling bawah. Peningkatan curah hujan terjadi pada periode OND, akan tetapi masih berada pada nilai yang terendah. Curah hujan wilayah Lereng Timur dan Kepulauan memiliki fluktuasi yang cukup stabil. Peningkatan dan penurunan curah hujan mengikuti periode musim tidak berubah secara drastis, sehingga kedua wilayah ini stabil sepanjang tahun (Gambar 4). 


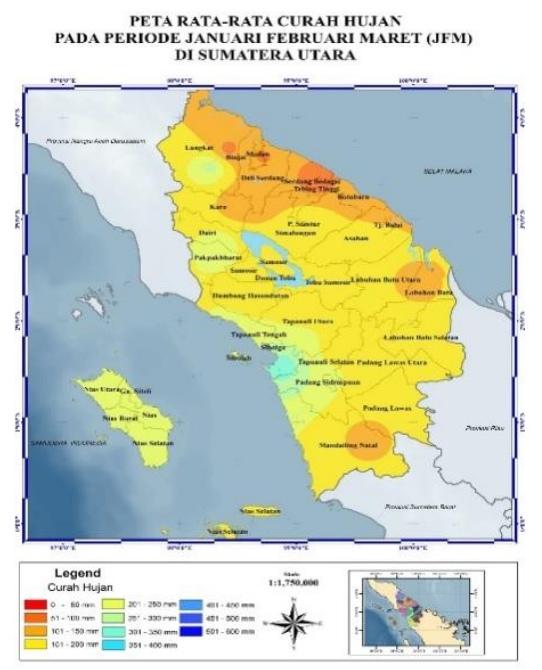

a.

PETA RATA-RATA CURAH HUJAN
PADA PERIODE JLLAGUSTUS SEPTEMBER (JAS) DI SUMATERA UTARA

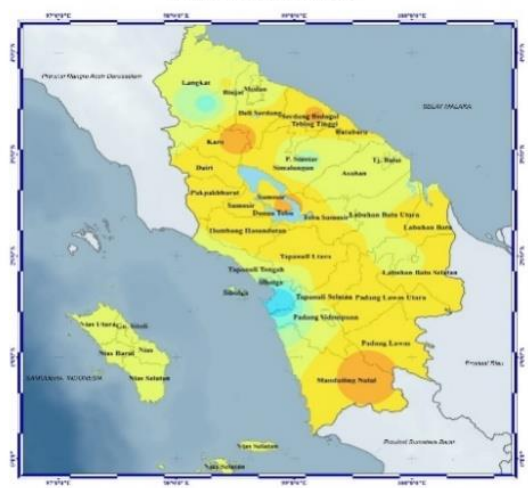

C.

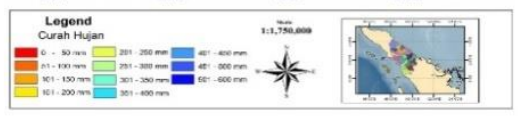

b.

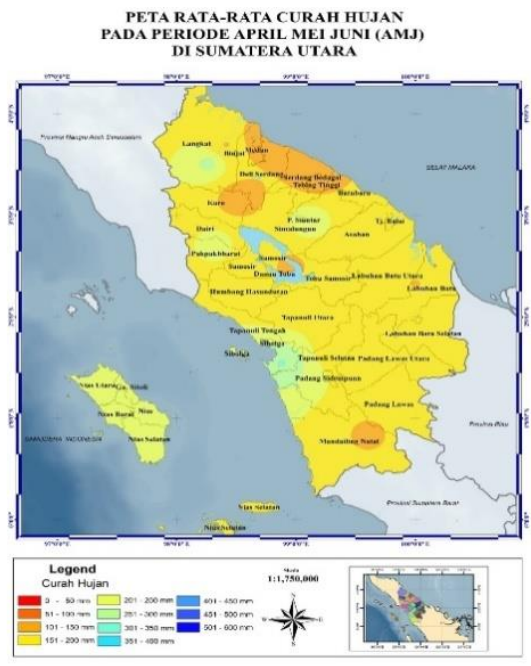

d. PADA PERIODE OKTOBER NOVEMBER DESEMBER (OND)
DI SUMATERA UTARA
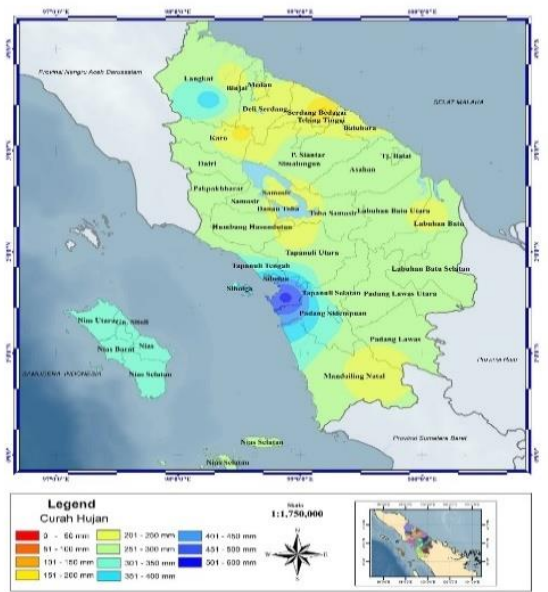

Gambar 3. Peta curah hujan rata-rata Sumut Antar Musiman pada periode (a). JFM, (b). AMJ, (c). JAS, (d). OND.

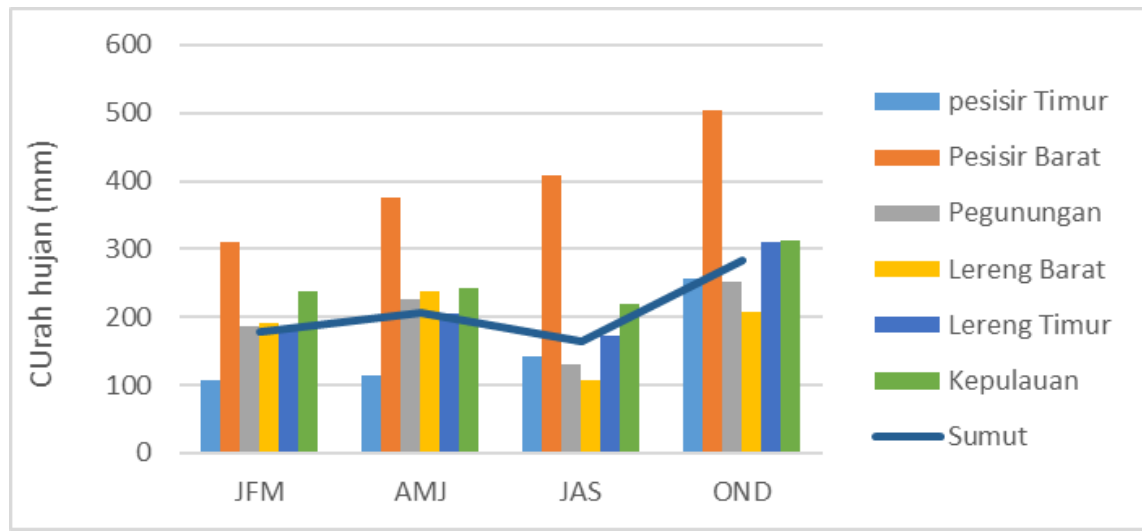

Gambar 4. Grafik curah hujan musiman wilayah topografi Sumut.

Dampak dari aktivitas gerak semu matahari terlihat sangat mencolok terhadap curah hujan musiman Sumut. Matahari melewati ekuator sebanyak dua kali yaitu pada bulan Maret dan Oktober sehingga menyebabkan curah hujan di sebagian besar wilayah Sumut cenderung lebih tinggi pada periode JFM dan OND. Pengaruh lokal seperti topografi dan lokasi dapat mengurangi dampak dari aktivitas semu matahari tesebut seperti yang terjadi di Pegunungan dan Pesisir. Selain itu adanya pengaruh dari faktor luar (eksternal) seperti IOD, ITCZ, ataupun monsun, juga dapat mempengaruhi intensitas curah hujan yang terjadi.

Wilayah Pesisir Barat dan Timur mengalami peningkatan secara terus-menerus sejak periode JFM hingga puncaknya terjadi pada periode OND. Pola curah hujan musiman yang terbentuk di 
kedua wilayah ini sangat berbeda dari pola Sumut pada umumnya. Penurunan baru terjadi ketika memasuki perubahan tahun yang baru dimana penurunan yang terjadi di awal tahun sangat drastis hingga hampir mencapai setengahnya. Perubahan suhu permukaan laut dapat berpengaruh terhadap perubahan ITCZ yang menyebabkan perubahan musim dari normalnya. Hal ini berakibat pada perubahan pola hujan yang sangat sensitif terhadap anomali suhu permukaan laut (Habibie, 2014).

\subsection{Curah Hujan Tahunan}

Curah hujan tahunan Sumut cukup tinggi dengan akumulasi jumlah curah hujan dalam setahun berkisar antara 1800 hingga $>4500$ $\mathrm{mm} / \mathrm{tahun}$. Curah hujan tahunan wilayah Sumut tertinggi terjadi di wilayah Sumut Bagian Barat yaitu di Pesisir Barat dan Kepulauan Nias, sedangkan yang terendah terjadi di wilayah Pesisir Timur. Lebih lanjut lagi, wilayah Sibolga dan sekitarnya memiliki curah hujan tahunan dua kali lipat dibandingkan wilayah Serdang Bedagai, Karo, dan Mandailing Natal dengan intensitas $>4500 \mathrm{~mm} /$ tahun (Gambar 5.a dan 5.b).

Curah hujan tahunan Sumut umumnya meningkat dari wilayah Sumut Bagian Timur hingga ke Barat. Perbedaan yang cukup mencolok terjadi di wilayah dataran rendah yaitu antara Pesisir Barat dan Pesisir Timur. Hal ini dapat diakibatkan oleh pengaruh lokasi wilayah. Wilayah Pesisir Barat mendapat asupan massa udara basah yang lebih banyak dibandingkan Pesisir Timur. Massa udara tersebut berasal dari Samudera Hindia yang bergerak masuk ke wilayah Sumut dibawa oleh angin baratan yang pertama kali sampai di wilayah pesisir Barat. Adanya Bukit Barisan menyebabkan massa udara basah ini terhalang pergerakannya ke arah Sumut bagian timur. Hal ini menyebabkan Wilayah
Sumut Bagian Timur hanya mengandalkan curah hujan dari massa udara yang berasal dari Selat Malaka dan asupan massa udara basah yang dibawa monsun saat musim penghujan.

Curah hujan tahunan di wilayah dengan topografi tinggi (seperti di Lereng dan Pegunungan) berbanding terbalik dibandingkan dengan wilayah dataran rendah. Wilayah Lereng Timur memiliki curah hujan tahunan yang lebih tinggi dan semakin menurun di wilayah Pegunungan dan berakhir di Lereng Barat. Pengaruh dari pergerakan angin lembah dan pertumbuhan awan topografi sangat dominan terjadi. Massa udara yang dibawa angin lembah umumnya bergerak naik dari Lereng Timur. Faktor topografi menyebabkan pertumbuhan awan di Lereng Timur saat pergerakan massa udara naik hingga ke wilayah pegunungan. Sesampainya di wilayah Lereng Barat, pertumbuhan awan semakin berkurang akibat massa udara yang menuruni lereng sudah cukup kering. Massa udara yang berasal dari Samudera Hindia juga terhalang oleh Bukit Barisan sehingga massa udara yang sampai di wilayah Lereng Barat berkurang. Kedua hal ini hal ini menyebabkan pertumbuhan awan berkurang sehingga curah hujan juga berkurang.

Secara umum kecenderungan tren curah hujan tahunan di Sumut mengalami peningkatan. Peningkatan tren terjadi di wilayah Pesisir Timur, Pegunungan, Lereng Barat, dan Pesisir Barat. Peningkatan di wilayah Lereng Barat, Pesisir Barat, dan Pesisir Timur kurang signifikan. Peningkatan tren curah hujan tahunan yang paling signifikan terjadi di Wilayah Pegunungan. Hal kebalikan terjadi di Wilayah Lereng Timur dan Kepulauan yang mengalami tren penurunan curah hujan tahunan. Tren penurunan curah hujan tahunan di kedua wilayah tersebut umumnya kurang signifikan. a.

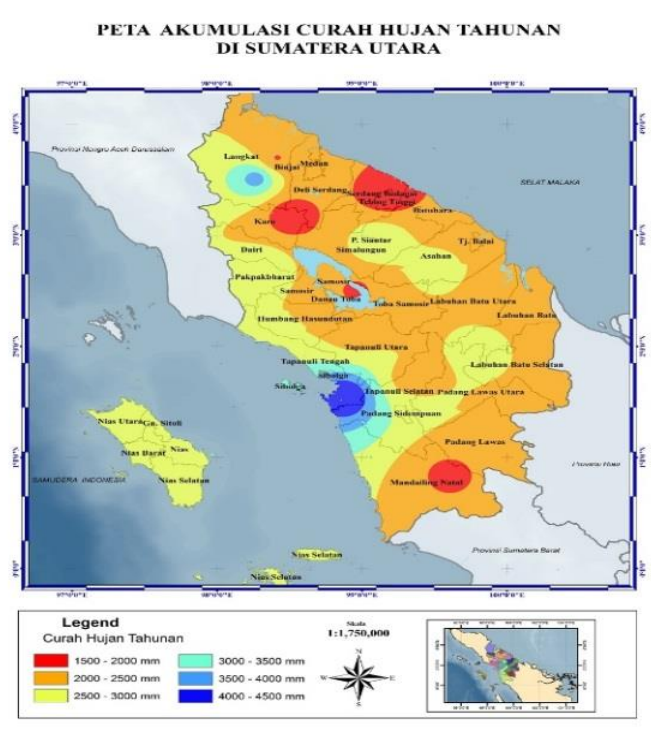

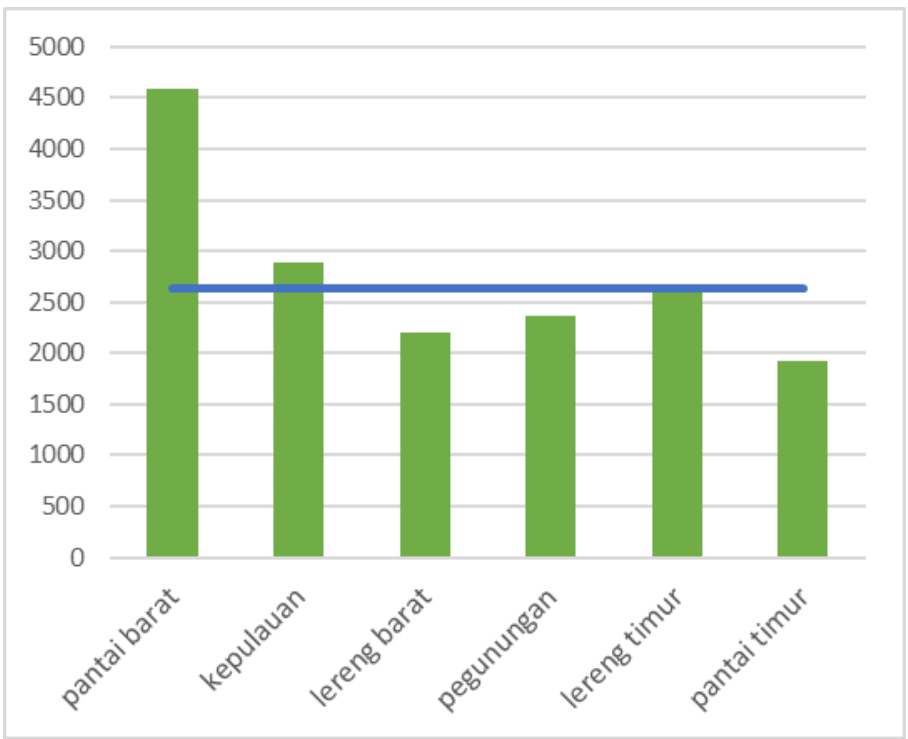

Gambar 5. (a). Peta Akumulasi Curah hujan Tahunan Sumut; (b). Grafik akumulasi curah hujan sumut dibagi berdasarkan wilayah topografi. Garis biru pada grafik merupakan akumulasi curah hujan Sumut secara keseluruhan. 


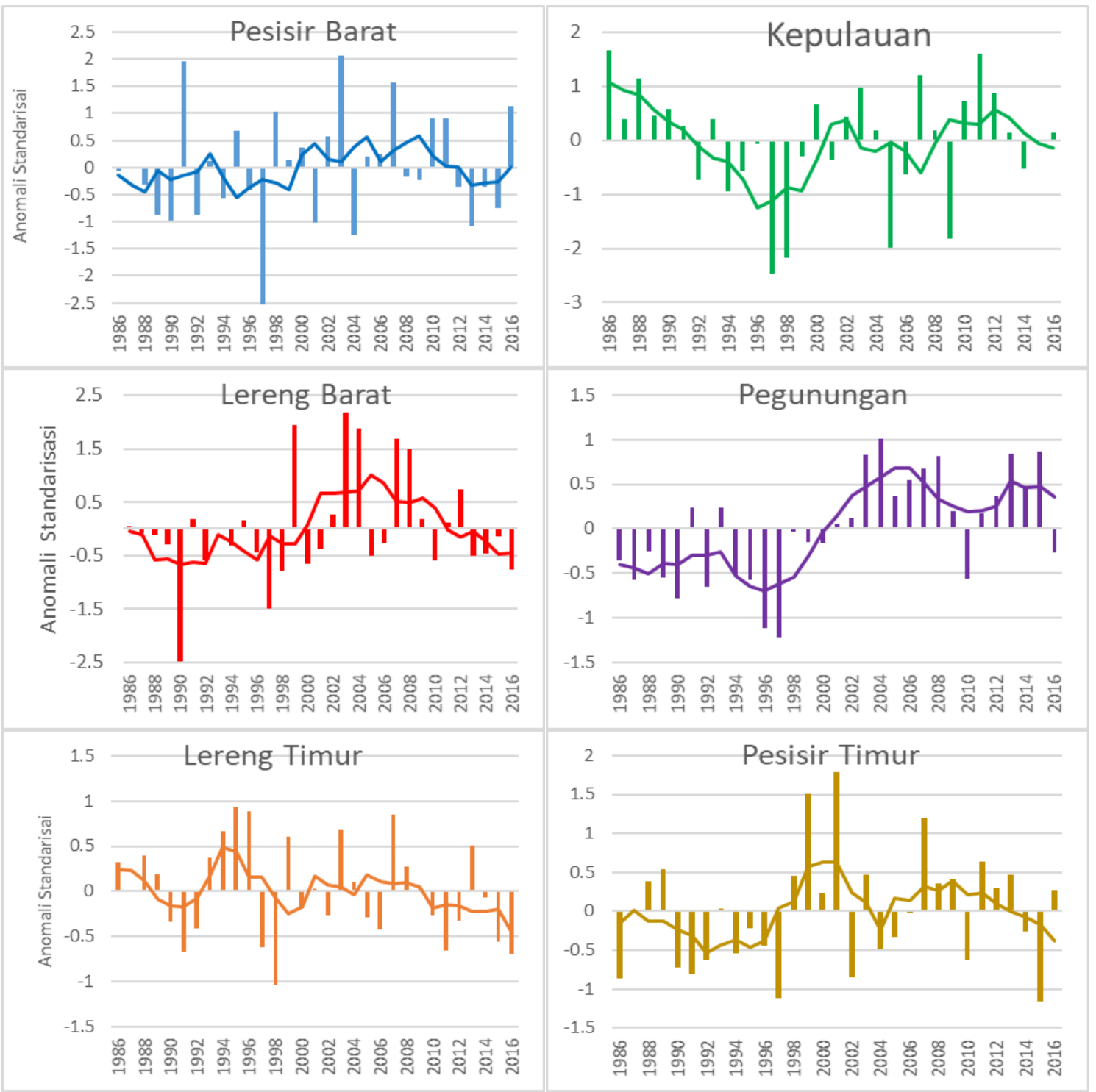

Gambar 6. Anomali standard (batang) dengan rata-rata lima tahunan (garis) wilayah topografi Sumut dari tahun 1986-2016.

Hasil perata-rataan 5 tahunan anomali standarisasi curah hujan tahunan menunjukkan bahwa curah hujan Sumut umumnya berbeda cukup signifikan antara satu dekade terakhir tahun 90-an dan setelah tahun 2000. Anomali curah hujan Bawah Normal terjadi dalam satu dekade yaitu tahun 1988-2000 sementara dalam 1 dekade terakhir (2001-2012) berada di atas normal (Gambar 6). Perubahan ini dapat disebabkan perubahan kondisi dari faktor luar yang berasal dari Samudera Hindia ataupun Samudera Pasifik. Curah hujan tahunan terkait dengan sistem cuaca osilasi tahunan seperti IOD dan ENSO. Dalam satu dekade terakhir fenomena ENSO didominasi oleh Central Pacific El Niño dengan magnitude yang lebih rendah dibandingkan El Niño konvensional (McPhaden, 2011). Hasil pantauan indeks IOD juga menunjukkan bahwa dalam satu dekade terakhir fenomena IOD umumnya berada pada kondisi netral.

Variabilitas anomali curah hujan tahunan Sumut menunujukkan variasi yang lebih besar di wilayah dengan topografi yang berbeda. Perbedaan anomali curah hujan tahunan tidak hanya terjadi antara tahun 90-an dan setelah tahun 2000, tetapi juga terdapat variasi lain. Anomali curah hujan tahunan di Pesisir Barat, Lereng Barat, Pesisir Timur dan Pegunungan umumnya menunjukkan kondisi yang sama seperti rata-rata Sumut yaitu berada dibawah normal tahun 90-an dan atas normal setelah tahun 2000.

Hal berbeda ditampilkan oleh wilayah Kepulauan dan Lereng Timur. Variabilitas curah hujan tahunan di Lereng Timur dan Kepulauan pada tahun 90-an menunjukkan variasi yang beragam. Wilayah Kepulauan berada pada kondisi Atas Normal dari tahun 1986-1991 kemudian berubah menjadi bawah normal dari tahun 1992-2000. Curah hujan tahunan di wilayah Lereng Timur mengalami fluktuasi yang lebih beragam tahun 90-an dibandingkan wilayah pegunungan akan tetapi dengan nilai anomali yang lebih kecil. Lereng Timur mengalami perubahan sebanyak 4 kali dalam rentang tahun 
90-an sehingga kondisi anomali curah hujan mengalami perubahan dalam rentang 3-4 tahun sekali. Kondisi Atas Normal terjadi tahun 19861988 kemudian menjadi Bawah Normal dari 19881992. Curah hujan tahunan berubah kembali menjadi Atas Normal dari tahun 1993-1997 dan menjadi Bawah Normal kembali dari 1998-2000.

Kondisi anomali curah hujan tahunan wilayah topografi Sumut setelah tahun 2000 menunjukkan fluktuasi yang lebih beragam dibandingkan tahun 90-an. Anomali curah hujan Atas Normal umumnya terjadi dalam satu dekade (2000-2010) dan berubah menjadi Bawah Normal dari tahun 2011-2016 yang terjadi di wilayah Pesisir Barat, Lereng Barat, Lereng Timur dan Pesisir Timur. Hal berbeda ditunjukkan di wilayah Pegunungan dan Kepulauan. Anomali curah hujan wilayah pegunungan menunjukkan kondisi stabil berada di atas normal setelah tahun 2000 hingga 2016. Lain halnya dengan wilayah Kepulauan yang menunjukkan variasi kondisi curah hujan tahunan yang berubah dalam rentang 6-7 tahun setelah tahun 2000. Anomali curah hujan Bawah Normal terjadi dari tahun 2003-2008 kemudian berubah menjadi atas normal dari tahun 2009-2014. Pengaruh dari faktor luar global seperti IOD dan ENSO terlihat berpengaruh sebagian besar wilayah Sumut. Fenomena El Niño disertai IOD Positif terjadi pada tahun 1994, 1997 (Qalbi et al., 2017), dan 2015 (Liu et al., 2017) dapat menyebabkan anomali curah hujan tahunan sebagian besar wilayah Sumut di bawah normal. Dampak fenomena tersebut memiliki pengaruh yang berbeda terhadap keenam wilayah di Sumut. Beberapa wilayah masih menunjukkan anomali curah hujan Atas Normal saat tahuntahun tersebut, misalnya Lereng Timur (tahun 1994), dan wilayah Pegunungan (tahun 2015). Dampak dari adanya fenomena global sangat berpengaruh di wilayah Pesisir Barat dan Lereng barat. Pengaruh lokal di kedua wilayah tersebut sangat dominan sehingga pengaruh global kurang berpengaruh.

\section{KESIMPULAN}

Curah hujan wilayah Sumut pada berbagai kondisi topografi dan geografi sangat bervariasi. Kondisi curah hujan rata-rata wilayah Sumut umumnya menurun dari wilayah Barat ke Timur sehingga menyebabkan perbedaan yang cukup signifikan antara wilayah Timur dan Barat. Curah hujan tertinggi terjadi di wilayah pesisir Barat yaitu di wilayah Sibolga dan sekitarnya dengan curah hujan rata-rata bulanan $230-570 \mathrm{~mm} /$ bulan atau rata-rata tahunan $>4550 \mathrm{~mm} /$ tahun. Curah hujan terendah umumnya terjadi di wilayah Pesisir Timur yaitu di wilayah Serdang Bedagai dan sekitarnya dengan curah hujan rata-rata bulanan $100-150 \mathrm{~mm} /$ bulan atau rata-rata tahunan 1500 $2000 \mathrm{~mm} /$ tahun.

Puncak curah hujan bulanan Sumut wilayah Timur (Pesisir Timur dan Lereng Timur) terjadi pada bulan Oktober, satu bulan lebih cepat daripada puncak musim hujan pada umumnya. Puncak musim kemarau umumnya berbeda antara wilayah bagian Barat dan Timur yang mana wilayah Sumut Bagian Barat (Pesisir Barat, Lereng Barat dan Pegunungan, kecuali Kepulauan Nias) terjadi pada bulan Juni sedangkan Wilayah Sumut Bagian Timur (Pesisir Timur, dan lereng Timur) terjadi pada bulan Februari.

Curah hujan tahunan Sumut umumnya mengalami perbedaan anomali standar curah hujan antara tahun 90-an yang mengalami anomali negatif (penurunan dari rata-ratanya) dan setelah tahun 2000 yang mengalami anomali positif (kenaikan dari rata-ratanya). Hal berbeda ditunjukkan oleh wilayah Lereng Timur dan Kepulauan, dimana variabilitas curah hujan tahunan lebih beragam. Selain itu, tren curah hujan pada kedua wilayah tersebut juga menunjukkan penurunan meskipun tidak terlalu signifikan, sedangkan wilayah lain menunjukkan tren peningkatan curah hujan.

\section{DAFTAR PUSTAKA}

Aldrian, E., Susanto, R.D. (2003). Identification of Three Dominant Rainfall Regions within Indonesia and Their Relationship to Sea Surface Temperature. International Journal of Climatology, 23(12), 1435-1452. doi: 10.1002/joc.950

Anders, A.M., Roe, G.H., Hallet, B., Montgomery, D.R., Finnegan, N.J., Putkonen, J. (2006). Spatial Patterns of Precipitation and Topography in the Himalaya. Tectonics, Climate, and Landscape Evolution, 398. The Geological Society of America.

Baidu, M., Amekudzi L.K., Aryee, J.N.A., Annor, T. (2017). Assessment of Long-Term SpatioTemporal Rainfall Variability over Ghana Using Wavelet Analysis. Climate 2017, 5(2), 30. doi: 10.3390/cli5020030

BPS. (2017). Sumatera Utara Dalam Angka Tahun 2017. Badan Pusat Statistik Provinsi Sumatera Utara.

Duran, C. (2014). Relationship between Rainfall Distribution and Physical Geography Elements within Mersin Province, Turkey. Procedia - Social and Behavioral Sciences, 120, 740-748. doi: 10.1016/j.sbspro.2014.02.157

Enyew B.D., Steeneveld, G.J. (2014). Analysing the Impact of Topography on Precipitation and Flooding on the Ethiopian Highlands. Journal of Geology \& Geophysics, 3(6). doi: 10.4172/2329-6755.1000173

Flesch, T.K., Reuter, G.W. (2012). WRF Model Simulation of Two Alberta Flooding Events and the Impact of Topography. Journal of Hydrometeorology, 13(2), 695-708. doi: 10.1175/JHM-D-11-035.1 
Gustari, I. (2009). Analisis Curah Hujan Pantai Barat Sumatera Bagian Utara Periode 1994-2007. Jurnal Meteorologi dan Geofisika, 10(1), 29-38. doi: 10.31172/jmg.v10i1.31

Habibie, M.N., Nuraini, T.A. (2014). Karakteristik dan Tren Perubahan Suhu Permukaan Laut di Indonesia Periode 1982-2009. Jurnal Meteorologi dan Geofisika, 15(1), 37-49. doi: 10.31172/jmg.v15i1.171

Hermawan, E. (2010). Pengelompokkan Pola Curah Hujan yang Terjadi di Beberapa Kawasan Pulau Sumatera Berbasis Hasil Analisis Teknik Spektral. Jurnal Meteorologi dan Geofisika, 11(2), 75-85. doi: 10.31172/jmg.v11i2.67

Hidayat R., Ando, K., Masumoto, Y., Luo, J.J. (2016). Interannual Variability of Rainfall over Indonesia: Impacts of ENSO and IOD and Their Predictability. IOP Confrence Series: Earth and Environmental Science, 31 (2016), 012043. doi: 10.1088/1755$1315 / 31 / 1 / 012043$

Liu L., Yang, G., Zhao, X., Feng, L., Han, G., Wu, Y., Yu, W. (2017). Why Was the Indian Ocean Dipole Weak in the Context of the Extreme El Nino in 2015?. Journal of Climate, 30(12), 4755-4761. doi: 10.1175/JCLI-D-16-0281.1

Manzanas, R., Amekudzi L.K., Preko, K., Herrera, S., Gutierrez J.M. (2014). Precipitation Variability and Trends in Ghana: An Intercomparison of Observational and Reanalysis Products. Climatic Change, 124(4), 805-819. doi: 10.1007/s10584-0141100-9

McPhaden, M.J., Lee, T., McClurg, D. (2011). El Niño and Its Relationship to Changing Background Condition In the Tropical Pacific Ocean. Geophysical Research Letters, 38(15). doi: 10.1029/2011GL048275

Mori, S., Hamada, J.I., Tauhid, Y.I., Yamanaka, M.D. (2004). Diurnal Land-Sea Rainfall Peak Migration over Sumatera Island, Indonesian Maritime Continent, Observed by TRMM Satellite and Intensive Rawinsonde Soundings. Monthly Weather Review, 132(8), 2021-2039. doi: $10.1175 / 1520-$

0493(2004)132<2021:DLRPMO>2.0.CO;2
Pabalik I., Ihsan, N., Arsyad, M. (2015). Analisis Fenomena Perubahan Iklim dan Karakteristik Curah Hujan Ekstrim di Kota Makassar. Jurnal Sains dan Pendidikan Fisika, 11(1).

Qalbi, H.B., Faqih, A., Hidayat, R. (2017). Future Rainfall Variability in Indonesia under Different ENSO and IOD Composites Based on Decadal Prediction of CMIP5 Datasets. IOP Confrence Series: Earth and Environmental Science, 54 (2017), 012043. doi: $10.1088 / 1755-1315 / 54 / 1 / 012043$

Roe, G.H. (2005). Orographic Precipitation. Annual Review Earth and Planetary Science, 33, 645-671. doi: 10.1146/annurev.earth.33.092203.122541

Sinambela, W., Dani, T., Rusnadi, I.E., Nugroho, J.T. (2008). Pengaruh Aktivitas Matahari pada Variasi Curah Hujan di Indonesia. Jurnal Sains Dirgantara, 5(2), 149-168.

Subyani, A.M., Al-Modayan, A.A., Al-Ahmadi, F.S. (2010). Topographic, Seasonal and Aridity Influences on Rainfall Variability in Western Saudi Arabia. Journal of Environmental Hydrology, 18, Paper 2.

Tjasyono, B. (1999). Klimatologi Umum. Bandung: Institut Teknologi Bandung.

Tjasyono, B., Bannu. (2003). Dampak ENSO pada Faktor Hujan di Indonesia. Jurnal Matematika dan Sains, 8(1), 15-22.

Wilks, D.S. (2006). Statistical Methods in the Atmospheric Sciences. Internatioanl Geophysics Series. Acedemic press, Elsevier Inc

Yang, X., Xie, X., Liu, D.L., Ji, F., Wang, L. (2015). Spatial Interpolation of Daily Rainfall Data for Local Climate Impact Assessment over Greater Sydney Region. Advance in Meteorology Vol. 2015, 12p. doi:10.1155/2015/563629

Yulihastin E., Febrianti, N., Trismidianto. (2010). Impact of EI Niño and IOD on the Indonesian Climate. National Institute of Aeronautics and Space (LAPAN). Indonesia.

Zhou, S., Wei, M., Wang, H. (2013). Topography Influences on Rainfall and Precipitation Distribution of Hunan Province. 2013 IEEE Third International Confrence on Information Science and Technology (ICIST). doi: 10.1109/ICIST.2013.6747705 